\title{
Students' Perceptions on The Effectiveness of Islamic and Asian Civilization Mooc as A Blended Learning Course
}

Adlina Ab. Halim, Normala Othman, Arfah Ab. Majid, Ahmad Nasir Mohd Yusof, Norasyikin Azri, Nasrina M Samir

To Link this Article: http://dx.doi.org/10.6007/IJARBSS/v11-i12/11990

DOI:10.6007/IJARBSS/v11-i12/11990

Received: 26 October 2021, Revised: 23 November 2021, Accepted: 12 December 2021

Published Online: 29 December 2021

In-Text Citation: (Halim et al., 2021)

To Cite this Article: Halim, A. A., Othman, N., Majid, A. A., Yusof, A. N. M., Azri, N., \& Samir, N. M. (2021). Students' Perceptions on The Effectiveness of Islamic and Asian Civilization Mooc as A Blended Learning Course. International Journal of Academic Research in Business and Social Sciences, 11(12), 2619-2632.

Copyright: (c) 2021 The Author(s)

Published by Human Resource Management Academic Research Society (www.hrmars.com)

This article is published under the Creative Commons Attribution (CC BY 4.0) license. Anyone may reproduce, distribute, translate and create derivative works of this article (for both commercial and non0-commercial purposes), subject to full attribution to the original publication and authors. The full terms of this license may be seen at: http://creativecommons.org/licences/by/4.0/legalcode

Vol. 11, No. 12, 2021, Pg. 2619- 2632

Full Terms \& Conditions of access and use can be found at http://hrmars.com/index.php/pages/detail/publication-ethics 


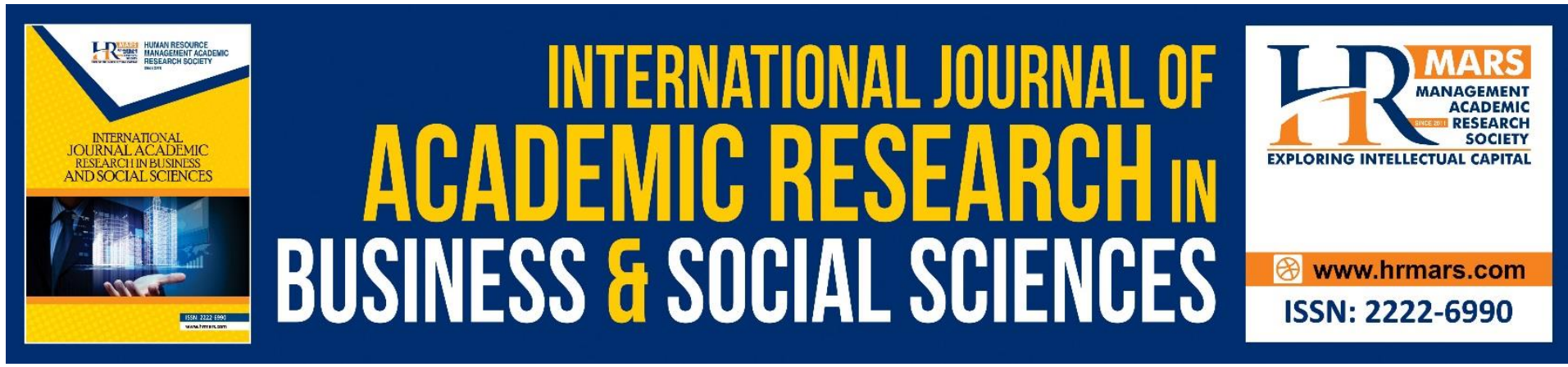

\title{
Students' Perceptions on The Effectiveness of Islamic and Asian Civilization Mooc as A Blended Learning Course
}

\author{
Adlina Ab. Halim¹, Normala Othman ${ }^{1}$, Arfah Ab. Majid ${ }^{1}$, \\ Ahmad Nasir Mohd Yusof ${ }^{1}$, Norasyikin Azri ${ }^{1}$, Nasrina M Samir ${ }^{2}$ \\ ${ }^{1}$ Department of Government and Civilization Studies, Faculty of Human Ecology, \\ Universiti Putra Malaysia, Malaysia, ${ }^{2}$ Department of Communication Technology and \\ Network, Faculty of Computer Science and Information Technology, Universiti Putra \\ Malaysia, Malaysia. \\ Corresponding Author's Email: adlina@upm.edu.my
}

\begin{abstract}
Blended learning is an integration of face-to-face, online teaching and learning process whereby it has been developed to improve the conventional learning method. Massive Open Online Courses (MOOCs) platform in Malaysia has been designed purposely to incorporate the blended learning approaches. Therefore, this study aims to examine students' perceptions on the effectiveness of Islamic and Asian Civilization MOOC as a blended learning course. The study employed a quantitative approach through survey method and purposive sampling was chosen as the sampling technique. The study was conducted among first year students in 19 Malaysian public universities by using an online questionnaire. A total number of 1373 public university students from five different zones were involved as respondents. The results revealed that the respondents have good perception on the effectiveness of MOOC platform with a mean score of 4.07. In addition, the finding also shows a significant relationship between student's perceptions on the effectiveness and their acceptance of MOOCs. The students' perspective also delineates that blended learning courses will positively impact the students' knowledge, motivation and soft skill. This study highlights the importance of the students' viewpoints in determining the effectiveness of a blended learning approach such as MOOCs.
\end{abstract}

Keywords: MOOC, Blended Learning, E-learning, Perception, Effectiveness

\section{Introduction}

The rapid development of digital technologies influences the diversity of teaching and learning strategies in our education system and encourages the development, innovation and transformation of teaching methods among academicians in Malaysia. The development of digital technologies in the era of Industrial Revolution 4.0 has improved the conventional faceto-face learning process and integrated it with e-learning. This situation allows students to attain the course through an online platform and encourages virtual and interactive learning experiences. The implementation of an e-learning setting, can impact both students and 
lecturers positively on the learning perseverance, behavior, collaboration and learning engagement (Chen \& Tseng, 2012; Ozdamli \& Uzunboylu, 2014). According to Rolstadas (2013), learning that integrates both conventional face-to-face learning and web-based learning is an effective method. It is more advantageous than using either conventional learning as a whole or virtual content only. Moreover, Mahajan \& Kalpana (2018) perceived that e-learning is useful, interactive and motivating the users for educational purposes. The proper usage of blended learning would enhance students' performance and teachinglearning experience.

In Malaysian public universities, blended learning approach has been implemented through MOOCs platform for numerous courses including Islamic and Asian Civilization course. This MOOC platform was developed as an added value, whereby the lecturers and students could practice blended learning which integrates both face-to-face learning and e-learning process. The integration of learning which implemented in Islamic and Asian Civilization MOOC have makes this course more attractive, effective and interactive (Ab. Halim et al., 2015). Therefore, this paper aims to examine the students' perception on the effectiveness of Islamic and Asian Civilization MOOC platform as a blended learning course.

\section{Development of e-learning}

The word ' $\mathrm{e}$ ' in e-learning can be understood as 'electronic' and it also can be described as evolving, extended, enhanced, everywhere, every time and everybody (Li \& Masters, 2009). It means that e-learning can be implemented at anywhere, anytime as long as there is an internet access. The e-learning method uses various media types such as virtual environment, video, animation, audio and text. The effectiveness of e-learning is also influenced by web usability, relationship, document, communication, tools management and knowledge to enhance the students' learning experience (Srimathi \& Srivatsa, 2008). Moreover, e-learning represents the integration of learning and technology usage as a learning tool through electronic devices. E-learning can also empower the users to be more informative and they can communicate diversely with the others in their learning environment.

Furthermore, Gupna et al (2013) highlighted that the quality of the e-learning system enhanced the quality of teaching in the educational sector. Besides, the development of elearning also depends on the popularity of social media and social interrelation that develop their learning capability via online (Hajili et al., 2013). On the other hand, e-learning aims to reform the culture of engagement among lecturers and students in order for them to contribute ideas, to attain more incredible accomplishment, to gain better achievement and to enhance learning effectiveness (Shipee \& Keengwee, 2014). Thus, the development of elearning and exploring students' perception about e-learning technologies is essential and both can contribute to the successful learning environment in the educational system (Ozdamli \& Uzunboylu, 2014).

\section{Islamic and Asian Civilization MOOC as a Blended Learning Course}

Massive Open Online Course or MOOC is a learning platform that allows global information sharing whereby the communication and interaction are active through online discussions. The platform provides learning opportunities worldwide for an individual to attain quality education similar to the conventional face-to-face learning without financial, time and localities constraints (Alias et al., 2016). The MOOC platform is accessible for massive 
interactive engagement and open access through global standard websites where it can receive large numbers of users at one time (Kop \& Carroll, 2011; Abdul Halim \& Aris, 2017; Nordin et al., 2015). In addition, MOOCs have been introduced by the Ministry of Education Malaysia as a teaching and learning platform since 2014 and Islamic and Asian Civilization was selected as one of the pioneer courses in public universities. This MOOCs flagship program are implemented to improve teaching and learning environment, save the costs, visibility, positioning and branding; global diversity and emphasize life-long learning (Yusoff, 2019; Mokhtar et al., 2019)

Blended learning can be understood as the incorporation of face-to-face conventional learning and e-learning. While the face-to-face learning is still implemented, integrating elearning settings will encourage an active learning experience. According to Cavanagh (2011) and Ismail et al., (2014) students who learn through blended learning can perform higher accomplishments than the students who are learning through conventional learning or online learning ultimately. Moreover, MOOCs platform can enhance the teaching and learning progress to be more interactive, active and effective. MOOCs in Malaysia have emerged as one of the new learning initiatives, collaborative and interactive with the discussions between the students from various institutional backgrounds to produce a blended learning process (Yusof, 2016). MOOCs platform for Islamic and Asian Civilization course involves lecturers' responsibilities in providing information regarding course outline, lecture notes, lecture videos, activities, quizzes, assessment and references. Therefore, the MOOCs platform can be considered as a one stop centre to enhance the process of blended learning for Islamic and Asian Civilization students as shown in Figure 1.

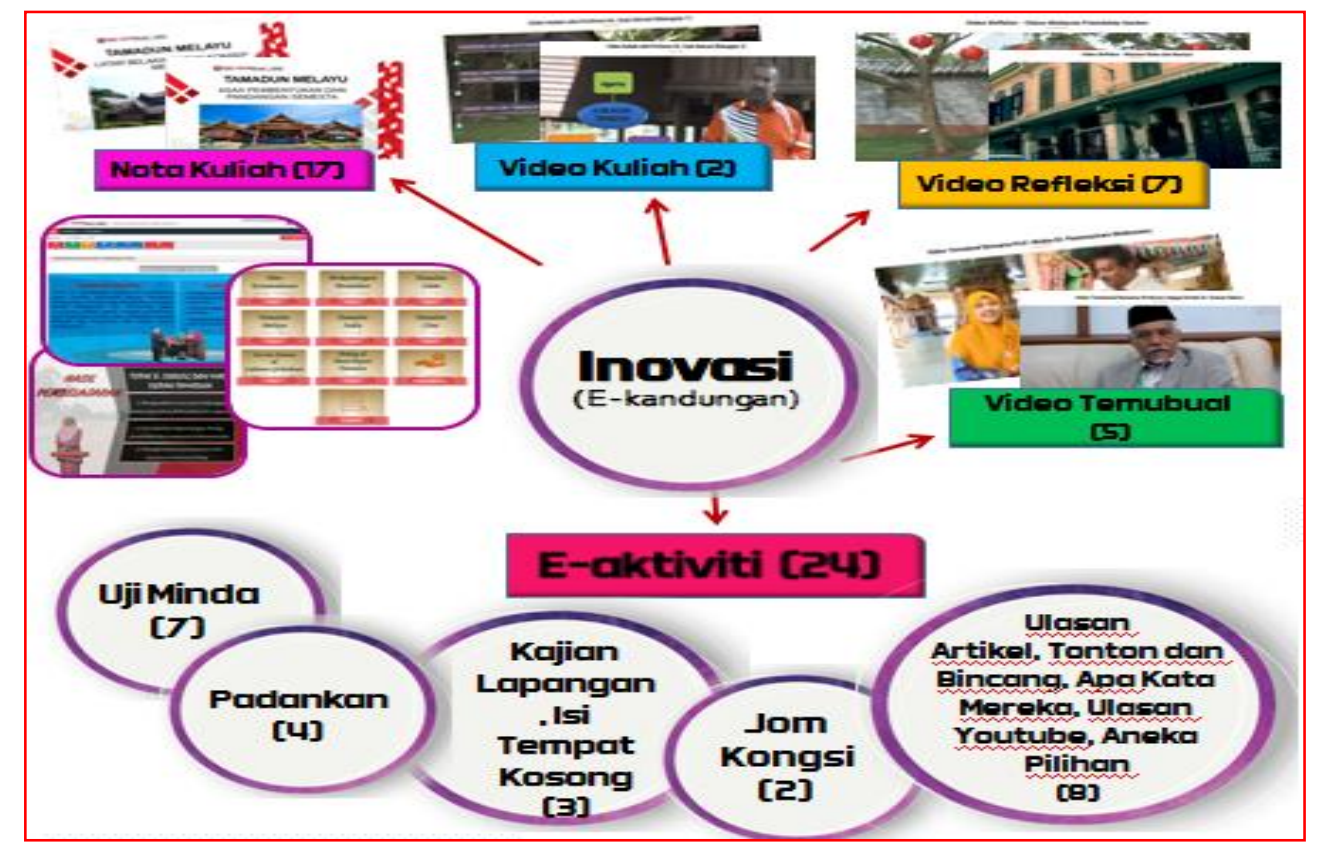

Sources: http://putramooc.upm.edu.my

Figure 1: Islamic and Asian Civilization MOOC Content

\section{Technology Acceptance Model (TAM)}

In accordance with the study, Technology Acceptance Model (TAM) is used to predict students' perceptions in using the Islamic and Asian Civilization MOOC platform. The emerging technologies in this digital era positively impacted the educational system and 
enhanced students' performance in learning. In past studies, Davis (1989) precedes a model namely as Technology Acceptance Model (TAM), which clarify the variables that derive computer acceptance among consumers who are using the computing technologies and the community whereby will helps scholars and practitioners to identify the reasons of unacceptable any precise system and attempt convenient adjustment. The main idea of the model is to produce the essence for recognizing the influence of extrinsic factors on interior beliefs, attitude, and usage intention. The model was developed to accomplish this purpose by analyzing essential small-scale variables proposed by past studies related to the computer acceptance influential and cognitive, which uses Theory of Reason Actions (TRA) as the theoretical basis to represent the theoretical relationship between these variables (Davis, 1989). Perceived Usefulness (PU) and Perceived Ease of Use (PEOU) are two fundamental beliefs that act as influential factors in computer acceptance behaviors as shown in Figure 2 . Therefore, the study adopted the TAM model which helps to examine how the students perceived the new learning platform, resulting in different perceptions among them.

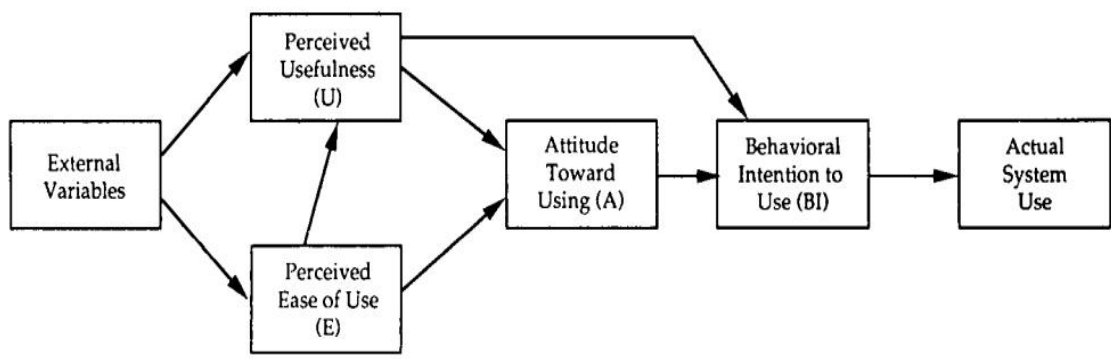

Figure 2. The TAM (Ref: Davis, 1989)

PU is the cognitive factor in TAM that indicates that individuals believe that their performance will be improved by implementing a precise system, whereas PEOU is indicating to the level of individual belief that the precise system used by them would be easy (Davis, 1989). In this study, the students' experience navigating through the platform can identify whether the system is user-friendly and increase their study performance or vice versa, which refers to students' perceptions based on the outcome from their experience. On the other hand, the student's acceptance of the platform depends on the benefits and evaluation of the student after using it. TAM also proposed that computer usage influence the behavioral intention on using the precise system, which was simultaneously determines by both PU and PEOU. Furthermore, past studies acknowledge, if the user realize that a precise system is easier to be use, the user is expected to realize that the precise system are useful too (Lau, 2008; Adams et al., 1992). Previous studies revealed that PU and PEOU have a strong significant influence towards IOU in TAM.

\section{Methodology}

The study employed a quantitative approach and was conducted among the first-year students in 19 Malaysian public universities by distributing online questionnaire instruments in the google form. The study used the purposive sampling technique and a total number of 1373 public university students from five different zones (North Zone, Central Zone, South Zone, East Zone, and Sabah/Sarawak Zone) were involved in the study as respondents. The research instrument has included questionnaires for the section of student's perception on 
the effectiveness of Islamic and Asian Civilization MOOC platform. The value of Cronbach's alpha for the pilot test was 0.972 .

This section contains three main elements, i.e., knowledge, motivation and soft skills. The first theme (knowledge) refers to the student's understanding, awareness and appreciation on the effectiveness of Islamic and Asian Civilization MOOC, while the second theme (motivation) implies the interaction and interactivity of the similar MOOC. The third theme (soft skills) signifies the effective communication, teamwork, leadership and flexibility while experiencing Islamic and Asian Civilization MOOC. Each item in this section is measured using the Likert Scale consisting of five items: 5-point Likert Scale ranging from 1 (strongly disagree) to 5 (strongly agree). Table 1 shows the number of items in this section and there are seven statements constructed for each element.

Table 1: The distribution of items in questionnaire instruments

\begin{tabular}{lll}
\hline Section & Elements & The Number of Items \\
\hline Students' perception on the Knowledge & 7 \\
effectiveness of Islamic and Asian & Motivation & 7 \\
Civilization MOOC platform & Soft skills & 7 \\
\hline The total number of items & & 21 \\
\hline
\end{tabular}

The students' perception on the effectiveness of the Islamic and Asian MOOC platform has been analyzed based on the items in the questionnaire form. The data were analyzed by using SPSS 25.0 software for descriptive and correlation analysis. The scale for the effectiveness was measured by classifying the intervals for each scale which is 1.33, as shown in Table 2 .

Table 2: The level of MOOC platform effectiveness

\begin{tabular}{ll}
\hline Level & Scale \\
\hline Effective & $3.68-5.00$ \\
Moderate & $2.34-3.67$ \\
Satisfying & $1.00-2.33$ \\
\hline
\end{tabular}

\section{Results and Findings}

This section discusses students' perception on the effectiveness of Islamic and Asian Civilization MOOC. The findings of the study were divided into 3 themes, i.e., knowledge, motivation and soft skills. The results revealed that public university students have a good perception on the effectiveness of MOOC platform that implemented in Islamic and Asian Civilization Course with a mean score of 4.07 as shown in Table 3 below. 
Table 3: Students' perception on the effectiveness of Islamic and Asian Civilization MOOC

\begin{tabular}{|c|c|c|c|c|c|c|c|c|}
\hline \multirow[b]{2}{*}{ No } & \multirow[b]{2}{*}{ Item } & \multicolumn{5}{|c|}{ Level of agreement (\%) } & \multirow[b]{2}{*}{$\begin{array}{l}\text { Mean } \\
\text { Score }\end{array}$} & \multirow{2}{*}{$\begin{array}{l}\text { Level of } \\
\text { effective } \\
\text {-ness }\end{array}$} \\
\hline & & SA & $A$ & $\mathrm{~N}$ & $\mathrm{D}$ & SD & & \\
\hline \multicolumn{9}{|c|}{ 1) Knowledge } \\
\hline & $\begin{array}{l}\text { I am able to understand the } \\
\text { civilization meaning clearly } \\
\text { through the videos provided in } \\
\text { MOOC TITAS. }\end{array}$ & $\begin{array}{l}35.5 \\
(488)\end{array}$ & $\begin{array}{l}42.1 \\
(578)\end{array}$ & $\begin{array}{l}18.4 \\
(253)\end{array}$ & $\begin{array}{l}3.1 \\
(42)\end{array}$ & $\begin{array}{l}0.9 \\
(12 \\
)\end{array}$ & 4.08 & Effective \\
\hline & $\begin{array}{l}\text { Through MOOC TITAS, I am aware } \\
\text { of the existence of similarities and } \\
\text { differences between different } \\
\text { civilizations. }\end{array}$ & $\begin{array}{l}37.4 \\
(514)\end{array}$ & $\begin{array}{l}43.9 \\
(603)\end{array}$ & $\begin{array}{l}16.5 \\
(226)\end{array}$ & $\begin{array}{l}1.5 \\
(20)\end{array}$ & $\begin{array}{l}0.7 \\
(10 \\
)\end{array}$ & 4.16 & Effective \\
\hline & $\begin{array}{l}\text { Through MOOC TITAS, I am aware } \\
\text { of the greatness of different } \\
\text { civilizations in terms of culture } \\
\text { and civilization. }\end{array}$ & $\begin{array}{l}37.4 \\
(513)\end{array}$ & $\begin{array}{l}44.9 \\
(616)\end{array}$ & $\begin{array}{l}16.0 \\
(220)\end{array}$ & $\begin{array}{l}1.2 \\
(16)\end{array}$ & $\begin{array}{l}0.6 \\
(8)\end{array}$ & 4.17 & Effective \\
\hline & $\begin{array}{l}\text { Through MOOC TITAS, I realized } \\
\text { that religion is essential in the } \\
\text { building of civilization. }\end{array}$ & $\begin{array}{l}41.8 \\
(574)\end{array}$ & $\begin{array}{l}42.5 \\
(583)\end{array}$ & $\begin{array}{l}14.1 \\
(194\end{array}$ & $\begin{array}{l}1.0 \\
(14)\end{array}$ & $\begin{array}{l}0.6 \\
(8)\end{array}$ & 4.24 & Effective \\
\hline & $\begin{array}{l}\text { Through MOOC TITAS activities, I } \\
\text { am interested in exploring } \\
\text { religions/ beliefs/cultures of } \\
\text { other civilizations. }\end{array}$ & $\begin{array}{l}36.0 \\
(494)\end{array}$ & $\begin{array}{l}43.2 \\
(593)\end{array}$ & $\begin{array}{l}18.4 \\
(252)\end{array}$ & $\begin{array}{l}1.5 \\
(21)\end{array}$ & $\begin{array}{l}0.9 \\
(13 \\
)\end{array}$ & 4.12 & Effective \\
\hline
\end{tabular}

6. Through MOOC TITAS, I appreciate the contributions of various civilizations in various fields such as technology, arts, $\begin{array}{lllllll}41.2 & 41.3 & 15.9 & 0.9 & 0.8 & & \\ (565) & (567) & (218) & (12) & (11 & 4.21 & \text { Effective }\end{array}$ and others.

7. MOOC TITAS activities are incapable of stimulating thinking and knowledge on the diversity of civilizations in Malaysia.

25.22.

Mean Score

8) 5)

2) Motivation

8. Through MOOC TITAS, I $\begin{array}{lllllll}\text { appreciate the importance of } & 39.3 & 44.1 & 14.9 & 1.0 & 0.7\end{array}$ interaction between different (540) (606) (204) (14) (9)

4.20 Effective civilizations.

9. I am aware of the importance of dialogue between civilization from the activities accomplished $\begin{array}{lllll}36.6 & 45.7 & 15.7 & 1.2 & 0.7\end{array}$ through MOOC TITAS.

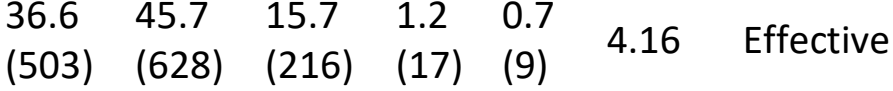

10. Through MOOC TITAS, I have positive point of view about the difference viewpoints in various $\begin{array}{lllll}39.2 & 44.6 & 14.9 & 0.8 & 0.5\end{array}$ (538) (612) (205) (11) (7)

4.21 Effective cultures and religions. 


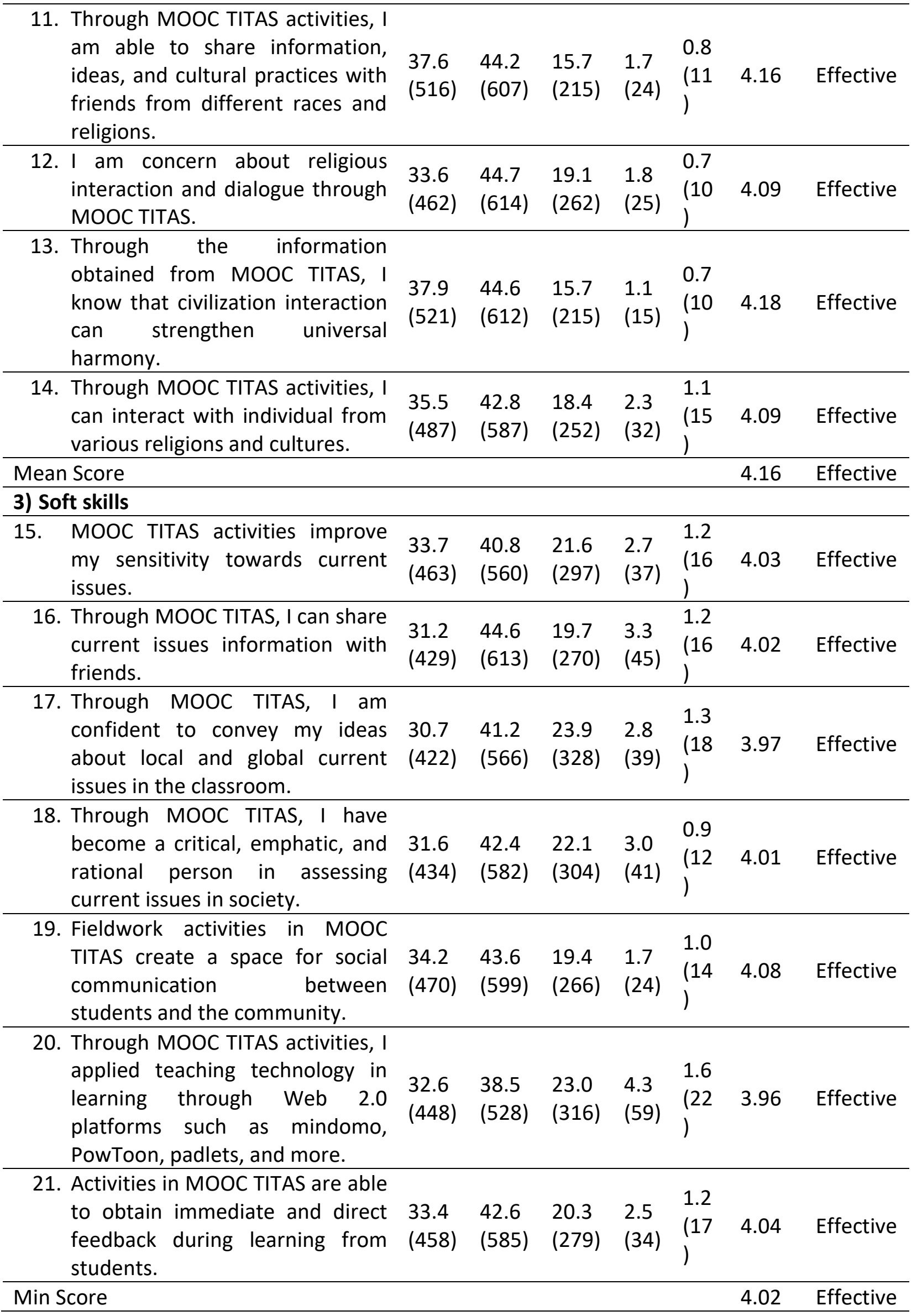


The findings of the study indicate that the adaptation of blended learning through the Islamic and Asian Civilization MOOC platform positively encourages on students' knowledge because the students perceive that this element is effective with a mean score of 4.03 . From the knowledge element, the study found that the majority ( $41.8 \%$ strongly agree, $42.5 \%$ agree) of the students have the congruent perception that the platform is effective to make them realized about the essential of religion in the building of civilization with a mean score of 4.24 (item 4). In comparison, only $1.6 \%$ of the students disagree with this statement. Indeed, most $(82.5 \%)$ of the students have a positive perception that blended learning through Islamic and Asian MOOC platform is effective and interactive. The contents of MOOC's platform also influenced them to appreciate the contributions of various civilizations in various fields such as technology, arts and others with a mean score 4.21 , while $1.7 \%$ of the students disagree with this statement (item 6). The findings indicated that blended learning through the Islamic and Asian Civilization MOOC platform also impacted students' knowledge in encouraging them to understand and be aware of the meaning of civilization, the existence of similarities and differences between different civilizations, and the greatness of various civilizations in terms of cultures and civilization.

The study also shows that students' perception on the effectiveness of Islamic and Asian Civilization MOOC platform is considered high for motivation element with a mean score of 4.16. From the motivation element, the study found that majority $(39.20 \%$ strongly agree, $44.60 \%$ agree) of the students agree that they have a positive point of view about the different viewpoints in various cultures and religions through Islamic and Asian Civilization MOOC platform (item 11 ). Besides, $39.30 \%$ strongly agree, and $44.10 \%$ agree that they appreciate the importance of interaction between different civilizations in their learning through the MOOC platform (item 8). Other than that, students have a positive perception on the MOOC platform that it is effective to motivate students' awareness on the importance of dialogue between civilization and religious interaction, encourage sharing of information, ideas, and cultural practices with friends from different cultures, races, and religions.

Moreover, the study also found that the MOOC platform effectively enhances students' soft skills with a mean score of 4.02 . Most $(77.8 \%)$ of the students are agreed that fieldwork activities in the platform create a space for social communication between students and the community, with a mean score of 4.08 , and only $2.7 \%$ disagrees with the statement (item 19). In addition, only $3.7 \%$ of the students are disagreeing that the activities in the platform are able to obtain immediate and direct feedback during learning from students, while $76 \%$ of the students are agreed that the platform is effective to attain immediate and direct feedback with a mean score 4.04 (item 21). Furthermore, the MOOC platform is effective to improve student's sensitivity towards current issues, enhance students' ideas and confidence in sharing the local and global current issues information with friends in the classroom; and inspire the students to become critical, emphatic, and rational people in assessing current issues in society. On the other hand, the students also applied teaching technology in their learning thru Web 2.0 platforms. 
Relationship between elements of students' perception on the effectiveness of Islamic and Asian Civilization MOOC

This section discusses the relationship between elements of students' perception of MOOC platform effectiveness as a blended learning. The findings of the study show significant relationships between the elements of students' perception of the effectiveness of MOOC platform. The results reveal significant relationships between students' knowledge and motivation with $p=0.00, r=0.864$; students' knowledge and soft skill with $p=0.00, r=0.823$; and students' motivation and soft skill with $p=0.00, r=0.877$. Since the $p<0.01$, the relationship between the variables is significant and the correlation values ( $r$ values) show a positive direction of the relationship (Cohen, 19880). Therefore, the relationships between students' knowledge, motivation and soft skills are in a high relationship. These results reveal that blended learning adapted in the Islamic and Asian Civilization course positively impacted students' knowledge, motivation, and soft skills. The results are shown in Table 4.

Table 4: Relationship between elements of students' perception on the effectiveness of Islamic and Asian Civilization MOOC

\begin{tabular}{|c|c|c|c|c|}
\hline & & 1 & 2 & 3 \\
\hline \multirow{3}{*}{ Knowledge (1) } & Pearson correlation $(r)$ & 1 & $0.864^{* *}$ & $0.823^{* *}$ \\
\hline & Sig. (2-tailed) & & 0.000 & 0.000 \\
\hline & $\mathrm{N}$ & 1373 & 1373 & 1373 \\
\hline \multirow{3}{*}{ Motivation (2) } & Pearson correlation $(r)$ & $0.864 * *$ & 1 & $0.877^{* *}$ \\
\hline & Sig. (2-tailed) & 0.000 & & 0.00 \\
\hline & $\mathrm{N}$ & 1373 & 1373 & 1373 \\
\hline \multirow{3}{*}{ Soft skill (3) } & Pearson correlation $(r)$ & $0.823^{* *}$ & $0.877^{* *}$ & 1 \\
\hline & Sig. (2-tailed) & 0.000 & 0.000 & \\
\hline & $\mathrm{N}$ & 1373 & 1373 & 1373 \\
\hline
\end{tabular}




\section{Relationship between students' perceptions and their acceptance towards Islamic and Asian Civilization MOOC}

This section discusses the relationship between students' perception and their acceptance towards the effectiveness of Islamic and Asian Civilization MOOC platform. The study shows a significant relationship between students' perception and their acceptance towards Islamic and Asian Civilization MOOC platform with $p=0.00, r=0.893$. Since the $p<0.01$, the relationship between the variables is significant and the correlation values ( $r$ values) show a positive direction of the relationship (Cohen, 19880). Therefore, the relationship between students' perception and their acceptance of MOOC platform effectiveness is high. The results are shown in Table 5.

Table 5: Relationship between students' acceptance and their perceptions towards Islamic and Asian Civilization MOOC

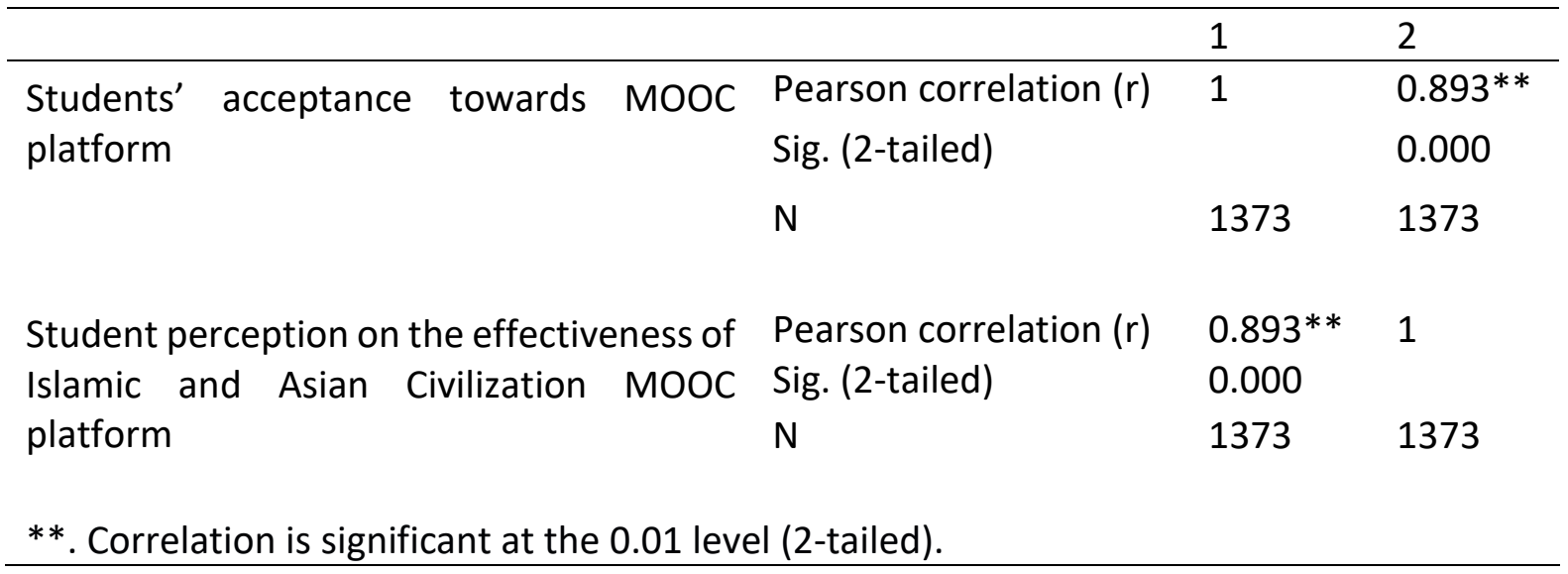

\section{Discussion}

Students' perceptions on the effectiveness of an online platform are about their capability to utilize digital technologies for a better accomplishment. The results reveal significant relationships between students' knowledge and motivation with $p=0.00, r=0.864$ and students' motivation and soft skill with $p=0.00, r=0.877$. The findings are in parallel with the previous studies regarding motivation among students. According to Castillo-Merino \& Serradell-López (2014), the variable which affects students' online performance is motivation, which is positively influenced by students' perception of their competency. This point of view was also supported by Bhuasiri et al (2012) that perceived motivation is one of three essential requirements for e-learning implementation to be successful.

In previous research, Mohammadi (2015) acknowledged that learners' perception on elearning is boundless and an essential contribution to the educational system. Therefore, the findings also reveal significant relationships students' knowledge and soft skill with $p=0.00$, $r=0.823$ and students' motivation and soft skill with $p=0.00, r=0.877$. The findings are in parallel with the previous studies regarding the importance of soft skills among students. Soft skill can be regarded as the value-added skills including critical thinking, problem solving, communication and etc. In the e-learning process, critical thinking is an impressive technique that helps to attain attention through the learning process and needs to be emphasized. A learner who can think critically is more adaptable, attentive, desiring knowledge, dedicated in fact-finding, concentrate on educational targets, and ready to encounter complex challenges. Critical thinking assists learners in focusing on their educational achievement 
progress. It is also essential to implement any platform that enhances collaborative communication among users. Besides, Samarraie et al (2013) discussed that systematic content contributes to improving e-learning attention, motivation, and interactivity, which will positively impact the students' thinking skills and enhance knowledge.

On the other hand, the findings of the study highlighted that an effective e-learning system must also provide interactivity. The keys to the success of the e-learning process are the interactions among the students and the interactions between lecturers and students. Moreover, the interactive and collaborative learning would make the teaching and learning process more effective, innovative, creative and improve learning outcomes (Palloff \& Pratt, 1999; Yusoff, 2019). Besides, student engagement through blended learning will enhance students' skills compared to students who take the traditional direct learning method (Yigzaw et al., 2019). Moreover, the blended learning approach has proven to be as effective as the conventional learning approach in broadening students' knowledge (Yigzaw et al., 2019).

Furthermore, Novo-Corti et al (2013) articulated that blended learning which integrates faceto-face learning and online learning can enhance students' involvement, motivation, competencies and performance. Therefore, MOOC platform adapted in Islamic and Asian Civilization course as blended learning has utilized the positive impact of e-learning by encouraging students' engagement. The interaction and students' engagement will generate activities of Student-Centered Learning (SCL), captivate attention, inculcate civilization values, unity, harmony, and aggregation of Islamic knowledge in the learning process (Yusoff \& Ali, 2018). Thus, blended learning adapted through Islamic and Asian Civilization MOOC platform is significant to positively enhance the students' knowledge, motivation and soft skills, communication, critical thinking and technology usage in the learning process.

\section{Conclusion}

This study revealed that the implementation and adaptation of blended learning in Islamic and Asian Civilization courses through MOOC platform effectively improve students' motivation, knowledge and soft skills. The effective and impressive online learning nowadays contribute largely to the development of e-learning in Malaysian educational system especially during the Movement Control Order (MCO) and pandemic period nowadays. Islamic and Asian Civilization MOOC platform has been designed purposely to incorporate virtual learning that allows the students to access the learning materials such as lecture notes, information, activities, videos, assessment etc. The teaching and learning progress is more flexible and impacts the students positively on their enthusiasm and learning performance via the accessible learning environment. The students' perspective also delineates that blended learning courses will positively impact the students' knowledge, motivation and soft skill. In addition, all these factors can indicate a better understanding of the course and improve students' learning productivity. This virtual e-learning approach also allows the students to conduct deeper and broader discussions without any time and location constraints. Thus, Islamic and Asian Civilization MOOC has established to be one of the best examples of elearning platforms for teaching and learning process in Malaysian public universities. In terms of novelty, this study highlights the importance of the students' viewpoints in determining the effectiveness of a blended learning approach such as MOOCs. The study strongly suggests that MOOCs method of blended learning should be integrated in all public universities in 
Malaysia in order to enhance students' knowledge, soft skills and motivation particularly during pandemic COVID-19.

\section{Acknowledgement}

The authors gratefully acknowledge University Putra Malaysia (UPM) for funding this research project under the grant of UPM Putra Grant. In addition, the authors would like to thank the MOOC TITAS Developers Team, students and TITAS coordinators at all public and private universities whom have involved in this study.

\section{References}

Halim, A., Yusoff M., A. N., Ab. Majid, A., Othman, N., Azri, N., \& Samir, N. M. (2019). Students' acceptance towards MOOC TITAS version 2.0 application in Malaysian public universities. Proceeding of Civilization, Ethnic and Turath Islami (pp. 80-86), Universiti Sains Islam Malaysia.

Adams, D. A., Nelson, R. R., \& Todd, P. A. (1992). Perceived usefulness, ease of use, and usage of information technology: A replication. MIS quarterly, 227-247.

Alias, B., Aziz, A., \& Jaafar, N. Z. (2016). National Academic Colloquium Book Program. Retrieved (21 September 2019): http://colloquiumilearn.uitm.edu.my/wpcontent/uploads/2016/08/buku-program1.pdf

Bhuasiri, W., Xaymoungkhoun, O., Zo, H., Rho, J. J., \& Ciganek, A. P. (2012). Critical success factors for e-learning in developing countries: A comparative analysis between ICT experts and faculty. Computers \& Education, 58(2), 843-855.

Castillo-Merino, D., \& Serradell-López, E. (2014). An analysis of the determinants of students' performance in e-learning. Computers in Human Behavior, 30, 476-484.

Cavanagh, T. B. (2011). The blended learning toolkit: Improving student performance and retention. Educause Review, 34(4), 15.

Chen, H. R., \& Tseng, H. F. (2012). Factors that influence acceptance of web-based e-learning systems for the in-service education of junior high school teachers in Taiwan. Evaluation and program planning, 35(3), 398-406.

Davis, F. D. (1989). Perceived usefulness, perceived ease of use, and user acceptance of information technology. MIS quarterly, 319-340.

Gupta, V., Chauhan, D. S., \& Dutta, K. (2013). Incremental development \& revolutions of Elearning software systems in education sector: a case study approach. Human-centric Computing and Information Sciences, 3(1), 1-14.

Hajili, M., Bugshan, H., Lin, X., \& Featherman, M. (2013). From e-learning to social learning-A health care study. European Journal of Training and Development, 37(9): 851-863.

Halim A., F. H., \& Aris, N. S. (2017). Students' perception on blended learning. Journal on Technical and Vocational Education, 1(2): 53-63.

Ismail, N., Ali, W. Z., Yunus, M. A. S., \& Ayub, M. A. F. (2014). The effects of blended learning methods on educational achievement and the development of online material in a Curriculum Information Document Online System (CIDOS) for Computer Application Courses. Malaysian Journal of Distance Education, 16 (2): 59-82.

Kop, R., \& Carroll, F. (2011). Cloud computing and creativity: learning on a massive open online course. European Journal of Open, Distance and E-Learning, Special Issue: Creativity and Open Educational Resources, 1-11.

Lau, S. H. (2008). An empirical study of students' acceptance of learning objects. Multimedia University. 
Li, H., \& Masters, J. (2009). E-Learning and knowledge management in the early years: Where are we and where should we go. Knowledge Management \& E-Learning: An International Journal, 1(4), 245-250.

Mahajan, M. V., \& Kalpana, R. (2018). A study of students' perception about e-learning. Indian Journal of Clinical Anatomy and Physiology; 5(4).

Mohammadi, H. (2015). Investigating users' perspectives on e-learning: An integration of TAM and IS success model. Computers in human behavior, 45, 359-374.

Mokhtar, M. R. A., Mohad, A. H., Sulaiman, M., \& Latiff, Ab. L. (2019). Blended learning in TITAS: A study on the usage of TITAS MOOC module among UMS students. Journal of Science Insani, 4(1), 54-60.

Nordin, N., Norman, H., \& Embi, M. A. (2015). Technology Acceptance of Massive Open Online Courses in Malaysia. Malaysian Journal of Distance Education, 17(2).

Novo-Corti, I., Varela-Candamio, L., \& Ramil-Díaz, M. (2013). E-learning and face to face mixed methodology: Evaluating effectiveness of e-learning and perceived satisfaction for a microeconomic course using the Moodle platform. Computers in Human Behavior, 29(2), 410-415.

Ozdamli, F., \& Uzunboylu, H. (2015). M-learning adequacy and perceptions of students and teachers in secondary schools. British Journal of Educational Technology, 46(1), 159172.

Palloff, R. M., \& Pratt, K. (1999). Building Learning Communities in Cyberspace: Effective Strategies for the Online Classroom. Jossey-Bass Higher and Adult Education Series. Jossey-Bass Publishers, 350 Sansome Street, San Francisco, CA 94104.

Rolstadås, A. (2013). Experience from continuing education using e-learning. Journal of Intelligent Manufacturing, 24(3), 511-516.

Samarraie, H. A., Teo, T., \& Abbas, M. (2013). Can structured representation enhance students' thinking skills for better understanding of E-learning content? Computers \& Education, 69, 463-473.

Shippee, M., \& Keengwe, J. (2014). mLearning: Anytime, anywhere learning transcending the boundaries of the educational box. Education and Information Technologies, 19(1), 103113.

Srimathi, H., \& Srivatsa, S. K. (2008). Knowledge representation in personalized elearning. Academic Open Internet Journal, 23.

Yigzaw, M., Tebekaw, Y., Kim, Y. M., Kols, A., Ayalew, F., \& Eyassu, G. (2019). Comparing the effectiveness of a blended learning approach with a conventional learning approach for basic emergency obstetric and newborn care training in Ethiopia. Midwifery, 78, 42-49.

Yusoff, M., A. N. (2016). MOOCTITAS course in open learning platform in UPM: Focus on concept, implementation and the unity of various race students. Journal of Umran, 2(1).

Yusoff, M. A. N. (2019). Massive open online course practices in teaching and learning of Islamic and Asian Civilization (TITAS) and Ethnic Relations (HE) in public and private universities. Proceeding of E-learning Carnival Competition (pp. 50-55). Universiti Teknikal Malaysia Melaka.

Yusoff, M. A. N., \& Ali, N. (2018). Massive Open Online Course in Teaching and Learning of Civilization of Islam and The Civilization of Asia (TITAS), Ethnic Relations (He) and Islamic Studies of 21st Century in Public and Private University. Proceeding of International Conference on Religion, Social Sciences and Technological Education, (pp 94-100). Universiti Sains Islam Malaysia. 